\title{
Comment
}

\section{Starting a TRO Project: Student Representation of Battered Women}

\author{
Gary Brown, Karin A. Keitel, and Sandra E. Lundy†
}

\section{INTRODUCTION}

This Comment presents a practical guide to establishing a legal assistance program managed by law students to obtain restraining orders ${ }^{1}$ for battered women. ${ }^{2}$ The experience of the Yale Temporary Restraining Order (TRO) Project for Battered Women demonstrates that a student-run program can effectively secure civil relief for battered women, while at the same time allowing attorneys to serve the community and law students to develop their interviewing, legal writing, negotiation, and advocacy skills.

Although the legal rights of battered women ${ }^{3}$ are receiving increasing attention, little practical advice is available to law students and attorneys

$\dagger$ The authors are J.D. candidates, class of 1988 and Directors of the Yale TRO Project for Battered Women for the academic year 1986-1987. The views expressed in this Comment are those of the authors. However, the Comment has been reviewed and approved by the other Directors and by our faculty advisor, Mary McCarthy.

We gratefully acknowledge the support and assistance of Mary McGarthy, Leah Knowlton, and Peter Kandel. Our special thanks to Amy Eppler, Yale J.D. 1986, student founder of the Yale TRO Project.

1. The terms "protection order" and "restraining order" are used interchangeably in this Comment to describe the civil relief available to battered women under state laws. We do not address the potential for criminal action against batterers.

2. Throughout this Comment, victims of abuse are referred to as women. Battering of men by women does exist, although its frequency is difficult to measure. See, e.g., Steinmetz, Wifebeating, Husbandbeating-A Comparison of the Use of Physical Violence Between Spouses To Resolve Marital Fights, in BAtTered Women: A Psychosociological Study of Domestic Vtolence 63-72 (M. Roy ed. 1977). Studies have shown that battering of women is a far more prevalent and ingrained problem. See generally R. DOBash \& R. DOBash, Violence Against Wives 17-19 (1979) (comparing battering by men and women).

3. For discussion of recent reforms in protection order legislation, see Lerman, A Model State Act: Remedies for Domestic Abuse, 21 HARv. J. ON LEGIs. 61 (1984); Note, Restraining Order Legislation For Battered Women: A Reassessment, 16 U.S.F. L. REv. 703 (1982). For background on battering, see R. Dobash \& R. Dobash, supra note 2; J. Fleming, Stopping Wife Abuse (1979); L. WALKER, THE BATTEREd WoMan (1979). 
who seek to use existing state laws to obtain protection orders for these women. Protection orders are available in forty-seven states and the District of Columbia. ${ }^{4}$ Unfortunately, overburdened legal aid offices may not have the resources to handle these actions on the emergency basis that they usually require. Private attorneys may be willing to represent battered women pro bono, but without an organized referral system clients may have difficulty locating these attorneys.

A TRO project is a practical way to meet this need. Directly or indirectly, the project can also serve other functions, such as fostering public awareness of the problems of battering, providing experience and local contacts for law students, enabling individuals to act on their commitment to social justice, and bringing the law school and the surrounding community into closer, cooperative contact.

We encourage law students to establish organizations similar to the Yale TRO Project. We hope to demonstrate that, with proper planning and commitment by students, operating a TRO project requires neither large sums of money nor other scarce law school resources. We believe that the framework of the Yale TRO Project can and should be adapted to similar organizations at law schools throughout the country in order to make protection orders more available to battered women.

In Section I, we describe how the Yale TRO Project works. Then, drawing upon our experience, in Section II we discuss several practical considerations that should be taken into account when establishing such an organization. Foremost among these considerations are verifying the need for such a project and identifying key features of state laws relevant to a student-run organization seeking to obtain protection orders for battered women. In Section III, we discuss issues that a student-run TRO project is likely to encounter, including the structure of the organization, the professional responsibilities of the law student intern, and the ethical problems that may be encountered in a TRO representation.

\section{The Yale TRO Project}

\section{A. Overview}

The Yale TRO Project was established in 1984 to provide free and easily accessible legal assistance to battered women in the New Haven area. The student-run association uses law students, supervised by volunteer attorneys, to perform legal work so that battered women receive immediate relief. ${ }^{5}$

4. See infra Section II.B.1.

5. Connecticut law provides for immediate relief to battering victims. See Conn. Gen. Stat. ANN. § 46b-15 (West 1986) (any adult subject to continuous threat of physical pain or injury by 
During the past two years, the Yale TRO Project has represented an average of forty clients per semester. Its success rate in obtaining restraining orders for clients is nearly $100 \%$. The Project currently involves thirty-seven attorneys and thirty-five students. Students are awarded one credit per semester for representing a client at an ex parte hearing, and may earn up to five during their law school career. ${ }^{6}$

When a battered woman calls the New Haven Legal Assistance Association or the New Haven Project for Battered Women (which operates a local battered women's shelter) ${ }^{7}$ and a volunteer determines that the woman might benefit from a protection order, the call is referred to a Project attorney. We provide these organizations with a monthly calendar listing the attorney and student designated to be on call for each day. ${ }^{8}$ The monthly calendar assigns two attorneys and two students to be on call for each day court is in session.

The attorney and the student meet with the client the day they receive the referral to counsel her on the protective relief available under Connecticut law. Under the attorney's supervision, the student interviews the client, drafts an affidavit, and completes the necessary legal papers based on outlines provided by the Yale TRO Project. Later that day, the attorney and the student represent their client in an ex parte hearing in state superior court. ${ }^{9}$ The ex parte order is effective for fourteen days and generally enjoins the batterer from assaulting the victim. ${ }^{10}$ Ideally, the ex parte order will be obtained on the day of the consultation; at the latest, the student and attorney arrange to meet at the courthouse on the following morning. At the ex parte level, court procedures vary depending on the individual judge. Many judges will grant ex parte TROs in chambers;

family member may apply to superior court for relief).

6. To qualify for a J.D. degree, Yale Law School students must complete a minimum of 81 units. No more than five of these units may be earned through participation in student-managed programs. See Yale Univ., Bulletin of Yale University, Series 82, Number 10, Yale Law School. 1986-1987, at 19-20 (Aug. 20, 1986) [hereinafter Yale LAw School. Bulletin].

7. The Yale TRO Project's relationship with the local battered women's shelter has been crucial to its operation. The shelter's referrals are a major source of the TRO Project's clients. In addition, the shelter provides an essential screening function by limiting referrals from its hotline to those individuals who are likely to benefit from the TRO process. Without this relationship, or a similar arrangement, a TRO project would have to establish a phone number to receive calls, advertise this number in the community and staff the phone with trained screeners. Establishing a hotline would be costly in terms of both financial resources and person-hours.

8. If the specified attorney cannot be reached, or has already been assigned a case, then the call is referred to the next listed attorney. See infra Section III.A.1.

9. Connecticut legislation provides for an ex parte order upon an allegation of "immediate and present physical danger to the applicant." Id. § 46b-15(b).

10. Ex parte orders should be fashioned as broadly as permitted by the judge to enjoin the batteres from contacting his victim at her home, place of work and any other areas she frequents. Connecticut law specifically permits orders granting temporary child custody, restraints on visitation, and possession of the victim's dwelling at the adversarial stage. At the ex parte level, the court may grant "such relief it deems appropriate." Id.; see infra notes 26-29 and accompanying text. 
others will require the victim to testify in open court but may call a TRO case early in that day's calendar to avoid unnecessary delay and anxiety. ${ }^{11}$ The client may seek a ninety-day extension of the ex parte order at an adversarial (show cause) hearing at which the alleged batterer may appear and object, with or without the benefit of counsel. ${ }^{12}$ During the fourteen days covered by the ex parte order, the student is primarily responsible for preparing for the adversarial hearing. The student ensures that the order is served, obtains hospital and criminal records, and completes any additional documents. The attorney and student accompany the client to the adversarial hearing and petition the court for a full protection order. At that hearing, the student may conduct direct and cross-examination of the victim and her alleged abuser, or may negotiate the terms of an extended protection order with the opposing counsel.

In its present form, the Yale TRO Project is efficient and effective. The current structure, however, has evolved, and continues to evolve, through trial and error. The following history of the Yale TRO Project provides both a description of the project's growth and suggests alternative methods of serving battered women.

\section{B. Founding of Yale TRO Project}

The Yale TRO Project was founded by Ms. Amy Eppler, then a law student, in close consultation with other students and with heads of the law school's clinical program, the New Haven Project for Battered Women, New Haven Legal Assistance, and the few local attorneys in private practice who represented TRO clients pro bono. ${ }^{13}$ All agreed that existing resources in the community were inadequate to meet the demand for legal services for battered women and that student interns could be used to meet that need. In addition, the organizers conceived of the Project as embodying a feminist vision of social justice: it would allow law students to help empower women by assisting them in obtaining some legal protection against domestic violence. ${ }^{14}$ By clearly establishing their goals

11. At the beginning of each semester, a representative from the Yale TRO Project meets with the local family court judges to explain the mechanics of the Project. During these visits, the representatives emphasize that because our attorneys volunteer their time, TRO cases should be given priority whenever possible.

12. Conn. Gen. Stat. Ann. $\$ 46 \mathrm{~b}-15$ (West 1986).

13. Interview with Amy Eppler, Staff Attorney, New Haven Legal Assistance, in New Haven (Nov. 19, 1986) [hereinafter Eppler Interview].

14. The process of obtaining a TRO for battered women has itself been criticized by feminists as perpetuating a paternalistic concept of the legal process. E.g., MacKinnon, Feminism, Marxism, Method and the State, 8 SigNs 635, 643 (1983) (applying battery laws to husbands fails to confront state's role in perpetuating causes of rape). Ms. Eppler states that she generally agrees with this analysis and notes that the original organizers of the Yale TRO Project too readily dismissed the possibility of conducting pro se courses. Eppler Interview, supra note 13; $c f$. Stallone, Decriminalization of Violence in the Home: Mediation in Wife Battering Cases, 2 Law \& IneQualtTy 493, 
from the start, the Yale TRO Project's organizers provided a base for subsequent practical and policy decisions as well as for continued growth and development. As we explain in later sections, however, the decision to start with a strong ideological focus has occasionally led to internal dissension.

The organizers considered a number of possible project designs and physical locations. Options included semester-long internships for individual students with local attorneys, New Haven Legal Assistance, or the New Haven Project for Battered Women, and affiliating the Project with the law school's clinical program. The organizers felt that although an internship could provide extensive experience to a few students, these students alone would not meet the community's need for legal services to combat domestic violence. Affiliating with the clinical program was simply impractical because attorneys in the clinical program were already overworked. As a result, the organizers chose to establish a pilot program under the joint auspices of the Yale Law Women's Association and the law school chapter of the National Lawyers' Guild. This program paired students with supervising attorneys on an on-call basis, similar to the present arrangement. The early effort, however, was not for academic credit. The pilot program shared its budget, administration, and resources with the two sponsoring organizations, and training was informal and ad hoc.

In the three years since its founding the Yale TRO Project has grown considerably. Initially, eight students joined the program, all of whom shared a common feminist orientation. Yet the small group was unable to meet New Haven's need for domestic violence legal volunteers. The student directors of the pilot program, and their community and law school advisors, began to consider ways to restructure the Project.

\section{G. Growth}

The restructuring aimed to attract additional students, maintain the program's integrity as a means of empowering women, and gain the support of the law school administration. The organizers felt that a creditgranting program would accomplish the first goal, and that a program unaffiliated with any other law school organization would have the greatest credibility among faculty, administration, and students. ${ }^{16}$ In designing the program, though, the organizers recognized that not all new participants would share the Project's feminist perspective and that therefore a

510-12 (1984) (mediation, as alternative to court proceedings, often perpetuates patriarchal stereotypes).

15. Yale Law School allows students to plan and run their own credit-granting student clinical programs, under the auspices of a supervising faculty member. See YAlE LAW SCHOOL BULLETIN, supra note 6, at 83-89. 
more formal system of introducing the program's goals and methods would be necessary. They developed a series of training sessions for the Project. They also apportioned separate tasks, such as training and scheduling, among individual directors. ${ }^{16}$

In restructuring the Project, the organizers also tried to anticipate objections, particularly financial objections, from the law school administration. Although the Yale Law School administration was in fact supportive of the Project, any attempt to establish a TRO project that does not address administrative concerns risks engendering indifference or hesitation on the part of deans and faculty. For instance, several founders wanted the Yale TRO Project to have its own office space within the law school, where students could phone attorneys and meet clients, and where meetings and training could take place. Most planners also agreed, however, that the budget-conscious school administration was unlikely to approve such a costly program. Eventually, the organizers abandoned the idea of separate facilities and restructured the Project so that no separate meeting room would be required.

Today, students are independently responsible for contacting attorneys on their on-call days and for meeting clients in the attorney's office; meetings and training take place in empty classrooms during evening hours. The only funds required are for mailings to attorneys, copying, and occasional social functions. These expenses have never exceeded the standard budget allotment for non-journal student-run organizations. ${ }^{17}$ Malpractice insurance for students is not necessary because the Project's faculty advisor is insured under the law school's general clinical insurance plan, and individual volunteer attorneys carry their own malpractice insurance. ${ }^{18}$ We believe that the relative economy of the new plan was a primary factor in persuading the law school administration to approve the Project as an accredited, independent student-run clinical program.

\section{Starting a TRO Project}

Law students considering forming a TRO project must first confirm that such an organization is actually needed in their community. They

16. See infra Section III.A.5. Present Directors generally recruit subsequent Directors from among Yale TRO Project participants. A Director serves for one academic year and may receive one or two academic credits per semester for Project work, with credit being awarded by the faculty advisor on the basis of the Director's individual Project workload. (Non-Director participants are rarely awarded more than one credit per semester.) Currently, the TRO Project has five Directors.

17. The current budget allotment from the Yale Law School is $\$ 600.00$ per year.

18. Attorneys are informed by Project recruiters that they are required to carry malpractice insurance. This policy does not pose a problem for most private sector attorneys, who carry their own malpractice insurance as a matter of course. It does, however, prohibit the Project from recruiting lawyers, such as those in government agencies, who do not carry malpractice insurance. 
should consider alternative responses such as pro se classes or internships at shelters. Throughout, students must be aware that state laws, which vary substantially, may determine the feasibility, and even the structure, of a TRO project. An examination of state law should begin with three areas: (1) the available forms of relief under the applicable domestic violence statute; (2) statutory provision for representation of battered women; and (3) student practice rules.

\section{A. Verifying the Need and Understanding the Alternatives}

First, students must determine that there is a need for a TRO project. Determining need requires more than discovering the existence of enabling laws. Students must consult with local lawyers and bar associations, legal aid societies, and, most importantly, community leaders in the battered women's movement ${ }^{18}$ to establish: (1) the incidence of battering in the target community; (2) the adequacy of existing resources to cope with the legal issues; and (3) the kinds of support services available to battered women. When existing resources are adequate (for instance, if the local legal aid society is able and willing to handle all the battering cases in a community), student organizers might investigate other ways to assist battered women, such as helping to staff the local shelter or providing childcare services while women seeking TROs are in court. The students' energy and commitment should not be wasted on unnecessarily duplicative services.

The next issue TRO organizers should consider is whether a studentrun TRO project is the best means of helping battered women. Alternatives include providing legal internships for individual law students in community battered women's shelters or legal aid societies, or establishing classes to train women to obtain protection orders pro se. The main advantage of these alternatives is that they bring the students more directly into the community. In addition, organizers may believe that pro se classes empower abused clients more than would the paternalistic process of going to a lawyer to obtain a protection order. A disadvantage of these alternatives is that they may not reach as many women as would a full-fledged TRO project, either because of the limited resources of existing support systems or because of the reluctance of many clients to face the intimidating machinery of the law on their own. Support services, such as volunteers to accompany women to court or to provide childcare, can alleviate the latter concern. Nevertheless, complex cases may arise which clearly

19. An up-to-date list of battered women's shelters and other support services for battered women can be obtained from the National Coalition Against Domestic Violence, 2401 Virginia Avenue, N.W., Suite 306, Washington, D.C. 20037, telephone no. 202-292-8860. 
call for the assistance of someone with legal training. Students contemplating pro se classes must also be aware of rules and laws prohibiting the unauthorized practice of law. ${ }^{20}$ There is a very fine line indeed between advising a person appearing pro se and giving legal advice.

Students must weigh carefully the advantages and disadvantages of each alternative organizational form, not only at the initial stages of a project, but periodically thereafter. Factors that may affect the original assessment include changes in state law or available community resources, changes in the client population, and changes in law school regulations. Indeed, awareness that a particular structure is neither inevitable nor fixed will allow a project to adjust more smoothly to evolving situations. Such flexibility is especially necessary because circumstances may force Directors to consider or reconsider whether to affiliate the project with the law school or a particular law school institution, whether to establish a credit or a non-credit program, or whether to have an office. In the historical overview of the Yale TRO Project, ${ }^{21}$ we discussed the particular reasons for our decisions when faced with these issues. Other projects must tailor their answers to their own particular needs and experiences.

\section{B. Relevant Law}

Once students determine that a TRO project is the most advantageous response to an existing need, they then must examine the relevant laws that govern protective relief, representation of battered women, and student legal practice.

\section{Available Forms of Relief}

Protection orders are available as a remedy for domestic abuse in almost every state and in the District of Columbia. ${ }^{22}$ Currently, Arkansas, Idaho, and Virginia are the only states without protection order legislation for battered women, although injunctive relief pending divorce is available

20. See, e.g., CoNN. Rules of CT. $§ 29$ (West 1986) (superior court may "punish and restrain any person engaged in the unauthorized practice of law"); $c f$. In re Sekerez, 458 N.E.2d 229, 237-39 (Ind. 1984) (attorney subject to disciplinary action for aiding non-lawyer in unauthorized practice of law by failing to monitor work of law student clerk in advising client in divorce case and preparing case for trial). See generally Annotation, Disciplinary Actions Against Attorney for Aiding or Assisting Another Person in Unauthorized Practice of Law, 41 A.L.R.4th 361 (1986).

21. See supra text accompanying notes 13-18.

22. For a comprehensive survey of protection order legislation, see Lerman \& Livingston, State Legislation on Domestic Violence, 6 Response 1 (1983). NOW Legal Defense AND Educ. Fund \& R. Cherow-O'Leary, The State-By-State Guide to Women's Legal Rights (1987) offers more current, though less detailed, reference to domestic violence legislation. In light of the rapid changes in this area of the law, any published material may prove unreliable after a relatively short period. See id. at 83-85. 
for battered wives in Idaho and Virginia. ${ }^{23}$ In these three jurisdictions, the type of TRO project described in this Comment would not be feasible. The orders available in other jurisdictions vary widely in both their structure and procedure. Projects must conform to the particular remedial provisions at hand.

\section{a. Types of Protection Orders}

Protection orders fall into two basic categories: "temporary" (or "emergency") protection orders, which are granted ex parte, and "full" protection orders, which are based on an adversarial hearing. The former are generally intended as preludes to the latter, affording interim protection until an adversarial hearing can be scheduled.

The Yale TRO Project provides representation for both temporary and full protection orders. Because domestic assault tends to recur, every case should be regarded as an emergency, and, ideally, counsel should seek immediate judicial relief for the client. ${ }^{24}$ To respond to these emergencies, the Yale TRO Project places two attorney-student teams on call for all court days. ${ }^{25}$ Ensuring that attorneys and students are available when needed allows the Project to achieve its top priority: providing immediate protection and relief.

\section{b. Substantive Provisions of the Protection Order}

In order to provide an effective remedy for domestic violence, a protection order must meet the client's needs. A simple "no-contact" order from the court is an inadequate response to the problems that most battered women face. Protection orders must address each client's particular situation, but financial and housing concerns arise most frequently. A protection order is unavailable if the woman cannot afford the court costs; similarly, the protection order will be ineffective if the woman lacks access to safe housing.

Housing considerations are paramount for victims who are abused by a household member. ${ }^{2 B}$ Because the overwhelming majority of incidents

23. See Lerman \& Livingston, supra note 22 , at 6-7, 20-26.

24. "[A] prompt response to the needs of victims of domestic violence is crucial. A delay of one or two days between petition and order could be dangerous to many petitioners." Lerman, supra note 3, at 93.

25. See infra Section III.A.1. The number of teams available should reflect the volume of the project: The Yale TRO Project rarely receives more than two calls per day. The Project is on call only when the courts are open. In order to assure this coverage, the Project needs a minimum of 20 supervising attorneys, each serving twice a month. Our present system, involving 37 attorneys and 35 students, in addition to the local battered women's shelter and one legal assistance clinic, provides adequate services for $\mathrm{New}$ Haven and the surrounding region.

26. "Exclusive possession [of the joint household] is the most important of the listed remedies. . . . The provision, in effect, creates for the victim the right to be safe at home. Although the 
handled by the Yale TRO Project involve cohabitants, housing is a major concern in almost every case. The most effective response is to include an order evicting the batterer in the protection order. This is permitted by statute in Connecticut ${ }^{27}$ and many other jurisdictions. ${ }^{28}$ Nevertheless, experience demonstrates that many judges are reluctant to order eviction in all but the most serious cases. Whenever possible, the victim requesting an eviction order should allege that the batterer has access to alternative housing arrangements. This allegation has softened judicial resistance to numerous requests by the Yale TRO Project for eviction orders. Once the protection order has been issued, the eviction is enforced by the processserver (accompanied by the police, if necessary), who escorts the victim to the home, ensures that the batterer vacates the premises, and seizes the batterer's keys.

Many statutes empower courts to order the batterer to provide alternative housing for the victim as an element of the protection order. ${ }^{29} \mathrm{Al}$ though such orders are difficult to enforce, this approach represents the best alternative to an eviction order.

Shelters and crisis centers are another source of safe housing. A few states have enacted statutes establishing state-funded shelters. ${ }^{30}$ Where statutory provisions for housing are unavailable, TRO project organizers must locate sources of safe housing for their clients. The New Haven Project for Battered Women ${ }^{31}$ offers housing and counseling to battered women represented by the Yale TRO Project. A TRO project should work closely with local shelter facilities where they exist.

Financial considerations are critical in many cases. Battered women, forced from their homes, are often denied access to their possessions, creating temporary indigence for clients who are usually able to pay. Court costs can thus present an immediate financial obstacle to applicants for protection orders. ${ }^{32}$ However, numerous states provide for the waiver of fees for indigent applicants who submit a financial affidavit with their application. ${ }^{33}$ Students who participate in the Yale TRO Project are supplied with sample financial affidavits and are trained to complete the necessary forms. Our experience cautions that some judges, protective of the

exclusion of a man from his own home may appear to be a radical form of relief, the remedy has been authorized in most states." Lerman, supra note 3, at 106 (footnote omitted).

27. Conn. Gen. Stat. AnN. § 46b-15(b) (West 1986).

28. See, e.g., D.C. Code ANN. $§ 16-1005$ (c) (Supp. 1986).

29. See, e.g., Ill. ANN. STAt. ch. 40, \& 2302-8(c)(2) (Smith-Hurd Supp. 1986).

30. See, e.g., id. at $\$ 2403$; ConN. GEN. STat. \$17-31k (Supp. 1986).

31. See supra note 7 .

32. At the present time, filing fees for a protection order in Connecticut amount to $\$ 90$, and sheriffs' fees for service of process are an additional $\$ 35$.

33. See, e.g., Conn. Rules of CT. $\S 50$ (West 1986); Gal. Civ. P. $\S 546.5$ (West Supp. 1987) (waiving fees in cases relating to injunctions restraining domestic violence). 
public fisc, grant waivers only in cases of extreme need. Welfare recipients regularly receive waivers, but women who are employed rarely obtain assistance, even if the court fees impose a substantial burden. Most states that provide for court costs employ a waiver mechanism; however, a few jurisdictions allow the court to order the batterer to pay the expenses. ${ }^{34}$ This provision offers a next-best alternative to the fee waiver but raises enforcement problems. TRO projects operating in jurisdictions in which waivers and cost awards are difficult to obtain or are unavailable should endeavor to secure funding to subsidize or assume the court costs for women facing financial hardship. ${ }^{\text {s5 }}$

In a number of jurisdictions, orders to pay maintenance, child support, and/or restitution for injuries sustained from battering may be included in a protection order. ${ }^{36}$ The Yale TRO Project has had limited experience with such provisions: in Connecticut, temporary child support may be awarded under a statute, distinct from the TRO statute, which requires a separate legal proceeding. ${ }^{37}$ Project members are supplied with sample applications for temporary child support, custody, alimony and counsel fees to assist clients in pursuing these avenues of relief. ${ }^{38}$

\section{Statutory Provision for Representation of Battered Women}

A number of domestic violence statutes provide for legal representation of battered women. In several states, court clerks are required to help battered women file for protection orders. ${ }^{39}$ Other statutes empower courts to award attorney's fees to the victim. ${ }^{10}$ Although such provisions should eliminate the need for student representation of battered women, the mere existence of a statutory provision may not reflect the actual availability of services. Those assessing the need for a TRO project must evaluate the actual implementation of statutory provisions in their area.

The prospect of an award of attorney's fees in a protection order does not adequately guarantee representation for battered women for three rea-

34. See, e.g., D.C. Code ANN. § 16-1005(c)(8) (Supp. 1986).

35. If a TRO project or a supervising attorney offered to pay court costs for a battered woman, this aid would fall under the "benevolent aid" exception to champerty and maintenance prohibitions. "It is not maintenance for a person to furnish assistance, in money or otherwise, to a poor man to enable him to carry his suit." 14 C.J.S. Champerty and Maintenance $\$ 24$ (1939) (footnote omitted).

36. See, e.g., Dri. Code ANN. tit. 10, §950(4) (Supp. 1986).

37. See Conn. Gen. Stat. AnN. § 46b-37 (West 1986). Child support is not available on the ex parte level. Section 46b-15 grants a court the discretion to "make such orders as it deems appropriate for the protection of the applicant and such dependent children or other persons as the court sees fit." Id. at $\S 46 \mathrm{~b}-15$. In addition to an order of protection, $\S 46 \mathrm{~b}-15(\mathrm{~b})$ specifically empowers courts to provide custody or visitation, but does not address the problem of support. $I d$.

38. See infra text accompanying note 52 .

39. See, e.g., VT. STat. ANN. tit. 15, § 1104(c) (Supp. 1986) ("Form petitions and form orders shall be provided by the Court administrator and shall be maintained by the clerks of the courts.").

40. See, e.g., Mass. Gen. Laws ANN. ch. 209A, § 3(e) (West Supp. 1986). 
sons. First, since many battered women are temporarily or chronically indigent, the risk of not prevailing in the action, and thus not receiving an award of attorney's fees, may dissuade women from seeking representation and may make attorneys reluctant to accept these cases. ${ }^{11}$ Second, even if the court issues a protection order, it might not order the batterer to pay attorney's fees. Finally, even when such awards are granted, they create tremendous enforcement problems, especially if the batterer, too, is indigent.

State-sponsored representation has met with greater success. Vermont law provides that court clerks must aid battered women seeking temporary protection orders. ${ }^{42}$ According to legal aid attorneys in Vermont, this system affords adequate representation for women during the ex parte stages of the proceeding. ${ }^{43}$ Generally, Legal Aid attorneys will represent battered women at the ten-day adversarial hearing that follows an ex parte order only if the respondent has retained counsel. ${ }^{44}$ Otherwise, women must rely on the guidance of Vermont's shelters in actions for full protection orders. Thus, in states similar to Vermont, a student-run project can shift its focus from providing representation for temporary protection orders to helping women seek full protection orders when Legal Aid is unavailable.

\section{Student Practice Rules}

The student practice rules of each state will, to some extent, define the student's role in the TRO process. ${ }^{45}$ Student organizers should take note of the state rules concerning the eligibility of students at a particular law school, ${ }^{48}$ procedures for student certification, and program requirements. Attorney supervision and student qualification requirements are of particular importance.

The Connecticut student practice rule requires that a member of the bar personally supervise a student's court appearance. ${ }^{47}$ Accordingly, the

41. In some states, a battered woman who does not prevail in an attempt to obtain a protection order may actually be ordered to pay the respondent's attorney's fees. See, e.g., ME. Rev. STAT. ANN. tit. $19, \S 766(1)(\mathrm{J})$ (West 1981).

42. VT. Stat. ANN. tit. 15, § 1104(c) (Supp. 1986).

43. Telephone interview with Sheila Reed, Staff Attorney, Vermont Legal Aid, in Burlington (Jan. 30, 1987).

44. This practice has lifted an enormous burden from legal assistance resources in the state. Generally, women who seek full protection orders do so pro se or with assistance from local battered women's groups.

45. For a comprehensive listing of student practice rules, see COUNSEL ON LEGAL EDUC. FOR Professional Responsibility, Inc., State Rules Permitting the Student Practice of Law: Comparisons and Comments (2d ed. 1973) [hereinafter Student Practice].

46. Under student practice rules of certain jurisdictions, only students attending law schools with ABA and/or state accreditation may be eligible to practice. See Student Practice, supra note 45, at 28-35 (Chart I).

47. Conn. Rules of CT. $\S 69$ (d) (West 1986). 
Yale TRO Project must assign an attorney to each case that it handles. Conversely, the ABA Model Student Practice Rules ${ }^{48}$ and many jurisdictions ${ }^{19}$ permit students to appear in court in civil matters without the personal supervision of an attorney. The more liberal student practice rules make it much easier to establish a TRO project, since it is difficult to recruit and maintain a group of attorneys willing to supervise student work and accompany students to court. ${ }^{\text {so }}$

Aside from requiring in-court supervisions by an attorney, the Connecticut rules are generous to law students: A properly supervised student may appear in state court after one semester of law school and the successful completion of an evidence test. ${ }^{\text {b1 }}$ Accordingly, the Yale TRO Project admits, and awards credit to, any interested law student who has completed one semester. The policy is arbitrary, however, because students are capable of assisting battered women even if they are not certified to practice in state court. Conducting the initial interview with a client, and drafting the affidavit and other necessary forms for a protection order, account for at least half of the hours spent in representation of battered women. Thus, students who are not certified to appear in court can make a genuine contribution to a TRO project. Therefore, projects can be established even in jurisdictions that lack student practice rules; in those states students can conduct interviews and draft documents, while volunteer attorneys appear in court.

\section{Sustaining the Project}

Establishing a TRO project may be easier than sustaining it. The project must recruit and train attorneys and students, schedule participants, and provide related services it deems necessary. In addition, the project must be sensitive to various considerations of professional responsibility and ethics.

48. See Student Practice, supra note 45, at 43 (app. A, Rule II(A)(1)).

49. See, e.g., D.C. CT. App. R. 48(a)(1); see also Student Practice, supra note 45, at 46-161 (reproducing state rules).

50. At present, there are 37 attorneys who volunteer to be on call once or twice a month for the Yale TRO Project. In any one semester, an attorney will be assigned to an average of two cases. The supervision of a TRO usually requires eight to 10 hours of the attorney's time. Nearly all of the attorneys report finding the representation of battered women a rewarding pro bono activity because it involves short-term cases. Several law firms have participated collectively, ensuring that one attorney is available on the firm's on-call days. Nonetheless, the Project has experienced substantial turnover, as attorneys often relocate or discover that the time constraints imposed by private practice preclude their continued participation. Of the 37 attorneys presently serving on the Project, 26 were participating one year ago. In that year, eleven new attorneys joined the Project, and twelve resigned.

51. Conn. Rules of CT. $\S 70$ (West 1986). 


\section{A. Organization of the Yale TRO Project}

The description that follows is not intended to be the definitive blueprint for student-run TRO projects. Every TRO project must be structured to respond to the particular needs, laws, and resources of the target community. However, the Yale TRO Project has been successful and efficient, and its structure may serve as a useful model for other projects.

\section{Schedule}

The Project issues a monthly schedule that assigns two attorneys and two students to be on call for each day that the court is in session. In addition, the schedule contains the telephone numbers of all Project participants and affiliated services, and any special notes for that month. A copy of this schedule is mailed to every participant. Usually, each student and attorney is on call twice per month, although special requests are accommodated. Once the schedule is issued, however, a student or attorney who is unavailable on a call day must find a replacement.

\section{Manual}

Student members of the Yale TRO Project have compiled and revised a ninety-six page manual that is distributed to the attorneys and students who participate in the Project. The manual is the central source of information for Project members. It contains an explanation of the Project, copies of the applicable statutes, an intake questionnaire, tips and checklists for the student, procedures for dealing with service of process and the police, and general information about battered women. In addition, the manual contains the forms used in the TRO process (one set completed with sample information, and a second blank set which may be photocopied and used in actual cases). ${ }^{52}$

\section{Board of Directors}

The Project is headed by five student committee Directors who constitute the Board. Most important among the Board's functions are coordinating efforts among the committees, dealing with faculty and administration, and selecting new Directors. Although the Board makes policy and operational decisions that touch the entire Project, its role is limited: Most decisions for a particular committee are made by its Director; the respon-

52. Law students or faculty members interested in forming a TRO project may obtain a copy of this manual from Yale TRO Project for Battered Women, Yale Law School, Box 401-A Yale Station, New Haven, GT 06520. 
sibility for each case is left to the attorney-student team to which it is assigned. Generally, the Board meets only as issues or problems arise.

\section{Faculty Advisor}

Although the faculty advisor does not supervise the day-to-day operations of the Project, she is responsible for overseeing the Project as a whole. The faculty advisor approves changes in the structure or focus of the Project, provides ongoing counsel to Project members on legal, ethical, or other Project-related matters, works closely with the Directors to coordinate efforts with New Haven's legal community, and represents the interests of the Project at the faculty level.

\section{The Committees}

In addition to handling cases, student participants are required to perform administrative tasks for the Project. These responsibilities are divided among the five committees described below. Five to ten students are assigned to each committee, and each student is expected to complete a minimum of twelve hours of committee work over the course of a semester. At the beginning of the semester the student selects or is assigned a committee and works with its director throughout the term.

\section{a. Training}

The training committee provides instruction to participating students and attorneys in both the technical aspects of obtaining a TRO and the most helpful ways to understand and talk with their clients. It is the largest and in many ways the most important committee. The committee organizes and supervises the initial training of students and attorneys, as well as conducting later training sessions designed to expand the awareness and understanding of Project participants. Initial training, aimed at students new to the Project and conducted by Project Directors, consists of two two-hour training sessions. The first session provides a general introduction to the problems of battering and related issues; the second focuses on the legal matters involved in the TRO process. Periodic events, open to all members of the Project, include guest speakers, workshops, and other activities designed to explore various aspects of domestic violence.

\section{b. Recruitment}

The recruitment committee is primarily responsible for recruiting supervising attorneys into the program. This task has been achieved in a number of ways. Most important, committee members contact local attorneys to explain the function of the Yale TRO Project, and to encourage 
individual attorneys or law firms to participate in the program. Since this is a cumbersome task, and involves responsibilities that are easily delegated, the recruitment committee is also large, often eight or nine students. Generally, prospective supervising attorneys are identified by current attorney-participants or by contacts at New Haven Legal Assistance. Publicity within the legal community has been largely by word-of-mouth; students make an effort to maintain frequent contact with the Project's attorneys in order to respond to their suggestions and complaints, and continually seek the names of prospective volunteers. To this end, the Yale TRO Project sponsors a reception each semester for Project participants, community leaders, and others interested in the program. Local lawyers' associations-most notably, women attorneys' groups-have also helped the Project to recruit new participants. In addition, the committee is responsible for recruiting new students for the program. As part of this effort, members of the committee visit first-term classes to explain the Project and encourage student interest. Finally, the recruitment committee is responsible for public relations with the community and with the press.

\section{c. Scheduling}

Organizing the on-call schedule is a demanding task. Members of the scheduling committee must contact all Project participants, students and attorneys alike, to ascertain scheduling preferences and limitations. Based on that information, the committee draws up a monthly calendar, which is then copied and distributed to all members of the Yale TRO Project, New Haven Legal Assistance, and the local battered women's shelter. Once an attorney-student team is assigned to a particular day, it is responsibile for coordinating meetings and appointments with any client referred to the Project on that day. In addition, the scheduling director handles scheduling conflicts and the emergencies that inevitably arise once the schedule takes effect. In our experience, the responsibilities of the scheduling committee can be performed by as few as three students.

\section{d. Divorce}

One of the more pressing problems faced by many clients of the Yale TRO Project is the need for divorce representation. Volunteer attorneys often are unwilling to represent women after the TRO stage, for financial or other reasons, and legal aid societies may not be able to accommodate the victims' longer-term needs. The Yale TRO Project has established a special committee to investigate this problem and suggest solutions. The divorce committee is exploring various responses, such as assisting with pro se divorce classes for battered women at New Haven Legal Assis- 
tance, and creating a student-run clinical program that could provide divorce representation for our clients.

\section{e. Police}

The police committee was created in response to concerns about lax and unenthusiastic enforcement of protection orders by the police. The committee monitors police enforcement of TROs obtained by the Project. After a client raises an enforcement problem, a member of the committee will contact her to discuss whether she would be willing to bring a complaint to the police department. If so, the committee contacts the department on the client's behalf. These complaints invoke the formal administrative process and help to promote awareness of domestic violence issues within the police department. The committee works closely with New Haven Legal Assistance and the local shelter to coordinate efforts to strengthen police enforcement of battering prevention laws.

\section{B. Professional Responsibilities}

A solid organization is not the only ingredient required to sustain a TRO project. Preparing students to understand professional responsibility issues will assure that a Project does not violate norms of legal conduct. The law student working with a TRO client will face, possibly for the first time, a variety of real-life professional responsibility issues. Under the attorney's supervision, the student will be advising a client about her legal options. The student may advocate the client's goals in open court ${ }^{53}$ or may negotiate a settlement on the client's behalf. Although decisions on ethical issues rest with the attorney, the student's conduct should also be guided by the Model Code of Professional Responsibility ${ }^{54}$ (Code) and the Model Rules of Professional Conduct (Rules). ${ }^{55}$ In the course of representing a victim, however, situations may arise for which neither the Code nor the Rules provide clear-cut guidelines. This section will consider the often ambiguous provisions of the Code and the Rules concerning both

53. See supra text accompanying note 51 .

54. Model Code of Professional Responsibility (1981) [hereinafter Model Code]. The Code, approved by the American Bar Association in 1969, has been adopted with some modifications or revisions by the supreme courts or legislatures of 49 states and the District of Columbia; the exception is Illinois, which drafted and adopted its own code. L. Patterson, Legal Ethics: The Law of Professional. Responsibility 6 (2d ed. 1984).

55. Model Rules of Professional Conduct [hereinafter Model Rules]. In 1977, the ABA appointed a Commission on Evaluation of Professional Standards to respond to perceived criticisms and limitations in the Code. In 1983, the ABA adopted the Rules that now supercedes the Code as official ABA policy. Id.

Since either the Code or the Rules may govern a lawyer's conduct within a given state, this section discusses both and notes differences in substance where relevant to a clinical program for battered women. 
lawyers' and students' professional responsibilities to the client and to the court.

\section{Duties Of the Supervising Attorney}

It is crucial to understand at the outset that, ultimately, the attorney is responsible for the student's actions. ${ }^{58}$ The attorney, not the student, must make all decisions regarding any professional responsibility issue. Should the attorney and the student differ on how to approach a particular case, the conflict must always be resolved in favor of the attorney's view.

Often, a student on the Yale TRO Project will be given considerable freedom in working with a client. The supervising attorney may only glance over the affidavit and court papers, delegating great responsibility to the student. Even in these situations, the student may not exercise discretion freely-where a potential ethical problem arises, the student must consult with the supervising attorney. Thus, it is imperative that students be able to recognize the ethical issues that arise while representing battered women.

\section{Accepting Representation}

When the student and attorney first meet with a potential client to discuss the TRO process, questions may arise concerning whether the project should offer representation: Does this client fit within the scope of the program? Should we represent her? The client involved in a protracted divorce may seem to be using the protection order to prevent potential, not actual, abuse. The client may recount psychological or verbal abuse, rather than physical harm. ${ }^{37}$ Or, if the client did sustain physical injuries,

56. Although the Code and Rules apply explicitly to attorneys, students should carefully adhere to these ethical standards. The Rules place an obligation on the attorney "having direct supervisory authority over the nonlawyer . . . to ensure that the person's conduct is compatible with the professional obligations of the lawyer." MODEl. Rules, supra note 55, Rule 5.3(b). The nonlawyer is not relieved of her obligations to adhere to professional responsibility norms by virtue of her lack of professional standing. It is likely that the attorney would incur liability for the non-lawyer student's actions. See supra note 20 . The Rules provide that a supervisory attorney "shall be responsible for conduct of [a non-lawyer] that would be a violation of the rules of professional conduct if engaged in by a lawyer if: (1) the lawyer orders or, with the knowledge of the specific conduct, ratifies the conduct involved; or (2) the lawyer . . . has direct supervisory authority over the person, and knows of the conduct at a time when its consequences can be avoided or mitigated but fails to take reasonable remedial action." MODEL RuLEs, supra note 55, Rule 5.3(c). Given the close working relationship between the law student and attorney in a TRO project, it is likely that the attorney would incur liability for the non-lawyer student's actions.

57. Walker identifies two types of psychological battering, which she terms economic and social. See L. WALKER, supra note 3, at 129, 165-66. According to Walker, a batterer may use money as "a coercive weapon" to deny the victim basic necessities and social freedom. Id. at 129-33. Social battering may consist of humiliation of the victim before her friends, or constant criticism of her attire or her abilities. This type of battering "result[s] in the same kind of social isolation, dependency, and loss of individuality that physical brutality produces." Id. at 166. Connecticut law recognizes the possibil- 
it may have taken her several weeks to get up the courage to seek a TRO. The state statute may not contemplate these situations, yet the attorney may believe that the client deserves a protection order. Should the attorney decline to represent a potential client who is not clearly within the statute? ${ }^{\text {s8 }}$

The Project should make every effort to ensure that any potential client will be represented. ${ }^{69}$ Even if the client's case is not clearly contemplated in the statute, the attorney should nonetheless make a "good faith argument" where possible for the extension of the protective statute into new areas. ${ }^{60}$ Thus, the attorney should not decline a representation simply because the abuse is either long past or seems only distantly possible. In the experience of the Yale TRO Project, threats and psychological abuse can be as harmful to the victim as physical violence. Nor does the fact that a victim waited several weeks after a beating to secure representation make her physical injury any less worthy of legal protection. Such arguments are consistent with the Code's view that the bounds of the law may change in accordance with "changing public and judicial attitudes." making distinctions among clients based on the attorney's perceptions of past judicial attitudes, the attorney has a responsibility to urge the courts to extend the law to accommodate changing public views.

Last year an attorney and student volunteering for the Yale TRO Project declined to represent a male client who had been beaten by his son. They suspected that the victim was beaten by his son in response to the victim's abuse of his wife; hence, he seemed less deserving of legal protec-

ity for psychological abuse by defining the standard for abuse as "a continuous threat of present physical pain or physical injury." ConN. Gen. STAT. § 46b-15(a) (West Supp. 1986) (emphasis added).

58. The Code and Rules provide minimal guidance on declining a representation. Under the Code, an attorney may, but "should not," represent a client if his or her "personal interests or desires" would "affect adversely the advice to be given or services to be rendered the prospective client." MODEL CODE, supra note 54, EC 5-2 (footnote omitted). The Rules provide an equally ambivalent justification for declining representation: where "the lawyer's . . . mental condition materially impairs the lawyer's ability to represent the client," refusal is mandatory. MODEL. RuLES, supra note 55, Rule 1.16(a)(2). Given that both the attorney and student have volunteered to assist battered women, it is unlikely that their personal desires and mental conditions would ordinarily warrant refusing to represent a client. But see infra text accompanying notes 68-69 (exceptions).

59. Indeed, the Code exhorts that attorneys "should not lightly decline proffered employment." MODEl Code, supra note 54, EC 2-26. The Code also recognizes that a lawyer is "under no obligation to act as adviser or advocate for every person who may wish to become his client." Id. It should be presumed, however, that all communications are confidential even if no representation ensues.

60. The Code permits this good faith argument on behalf of a client: "The advocate may urge any permissible construction of the law favorable to his client, without regard to his professional opinion as to the likelihood that the construction will ultimately prevail. His conduct is within the bounds of the law, and therefore permissible. ..." Id., EC 7-4 (footnote omitted); see also MODEL RuLEs, supra note 55, Rule 3.1. The Code recognizes that an attorney should represent a client "zealously within the bounds of the law." MODEL CODE, supra note 54, EC 7-1 (footnotes omitted). These boundaries may change or develop over time. Id. EC 7-2.

61. MODEL. CODE, supra note 54, EC 7-2. 
tion. In our opinion, this decision not to represent was inappropriate: An attorney should not evaluate the "worthiness" of a potential client's claims. ${ }^{62}$ Instead, where a client has asserted facts that represent a colorable claim under the relevant statute, the client must be represented. ${ }^{63}$ The ultimate decision of whether a claim is within the statute rests with the judge, not the attorney. Thus, "[w]hile serving as advocate, a lawyer should resolve in favor of his client doubts as to the bounds of the law."

This broad presumption in favor of representation must be tempered by three factors. First, despite the lawyer's obligation to represent a client zealously within the bounds of the law, representation must include giving the client a frank professional estimation of the potential outcome. ${ }^{65}$ For example, the attorney should warn a client who has been psychologically harassed but not physically battered that she may not be eligible for civil remedies. Similarly, the attorney must inform the client who suffered abuse weeks in the past, or the client who alleges only potential abuse, that relief may be more difficult to obtain or may not be granted. This open relationship is particularly important because many battered women will be unfamiliar with legalistic subtleties and thus may not understand why relief was denied. Openness also permits the victim to make an informed decision about her course of action; by denying a client the opportunity to make an informed decision, the attorney patronizes her and may ultimately alienate her further from the legal process.

Second, an obligation to represent clients does not mean that attorneys or students should pressure victims to seek TROs. Many women who seek help from the Yale TRO Project have conflicting emotions about taking

62. The student and attorney obviously depend upon the facts related by the client since they are unable to verify the incidents independently. Students may be confronted by stories they simply cannot believe; in these cases, they should delicately discuss their concerns with the client, rather than rejecting the client out of hand. Because many battered women have suffered in ways unimaginable to most law students, students should take care to discuss their concerns in a non-threatening and nonjudgmental manner. Battered women may place little trust in persons in positions of authority. To question their claims in an effort to assess their sincerity would only further discourage these women from seeking assistance. The student should instead attempt clearly to ascertain the type and frequency of abuse in order to present a strong case for the client.

63. It is important to distinguish good faith arguments on behalf of potentially meritorious cases from frivolous or harassing actions. If it appears that the only motivation for seeking a protection order is to anger the client's husband during a divorce action or to improve the chances that the client would receive custody of her children, representation may not be undertaken. See MODEl. CODE, supra note 54, DR 7-102(A)(1)-(2); Model Rules, supra note 55, Rule 3.1. Yet it is ethical to bring an action that will harass if it has some other legitimate purpose as well. See G. HAZARD, ETHics in the Practice of Law 39 (1978). An attorney certainly can discuss with the client her concerns that the protection order is being sought for harassment purposes. But see supra note 62 (danger of rushing to judgment).

64. Model Code, supra note 54, EC 7-3.

65. Id. The Rules state that a lawyer must explain a matter to the extent reasonably necessary to permit the client to make informed decisions regarding the representation. MoDEL RuLES, supra note 55 , Rule 1.4(b). 
legal action against their abusers. ${ }^{86}$ Attorneys and students should understand this ambivalence and not attempt to persuade a victim that a TRO is the right step for her. Only the client can and should decide what is right for her. ${ }^{67}$

Finally, although all clients should receive proper representation, a particular student and attorney need not represent a particular client. At times, a student may be uncomfortable taking on certain cases for personal reasons. The Yale TRO Project accommodated a student's desire to avoid participating in actions that could lead to divorce. This student was able to represent clients at the ex parte proceeding where the resulting order-designed to protect the victim from immediate physical danger-is only temporary. Another student was enlisted to represent the same client at the fourteen-day hearing, where an extended or permanent order could be obtained. A TRO project might encounter a student who has been a rape victim and is uncomfortable working with clients whose cases include similar violence. Such a student should be permitted to decline to work with a client whom she cannot represent comfortably, so long as the client is represented adequately by another qualified student. ${ }^{68}$ Arranging for another student to handle a particular client is consistent with the conception of a TRO project as a law firm, where mutual access to confidential information is permissible and necessary. ${ }^{69}$

66. In leaving the batterer, the victim may be giving up her status as a wife, see $R$. DoBASH \& $R$. DOBASH, supra note 2 , at 147 , a role that society perhaps has prepared her for since childhood. Id. at 75-90. Fear of independence in a society that encourages her dependency is a significant factor in decisions to stay with or return to the abuser. See id. at 146-47. In a study of 30 victims, women generally held "romantic delusions" about marriage, leading to a belief that their husbands could change or that "marriage must be preserved at all costs for the sake of their families." Truninger, Marital Violence: The Legal Solutions, 23 Hastings L.J. 259 (1971).

67. Students must recognize the subtle ways in which they may influence the victim. A battered woman may be particularly susceptible to pressure from authority figures such as attorneys or even law students. It is best, therefore, to describe her legal options without placing value judgments on them. Of course, the attorney or student may offer advice upon request. The advocate would nevertheless be wise to couch any advice in non-judgmental, non-authoritarian terms. A student could say, for example, that her advice represents a personal, not legal, view. It is appropriate for students and attorneys to allay fears which may accompany a TRO application, such as fear of testifying in court or fear of reprisals by the batterer. In those situations, the student and attorney may offer their genuine expertise on court or police procedures. They are not, however, experts on whether a TRO is the right choice in any given case.

68. Indeed, the Code requires an attorney to decline employment "if the exercise of [an attorney's] professional judgment on behalf of his client will be or reasonably may be affected by his own . . . personal interests." MODEL CODE, supra note 54, DR 5-101(A). Under the Rules, a lawyer may "limit the objectives of the representation if the client consents after consultation." MODEL RulEs, supra note 55, Rule 1.2(c).

69. The Rules state that if two or more lawyers present themselves to the public in a way that suggests they are a firm, or conduct themselves as a firm, they should be regarded as a firm for purposes of the Rules. MODEl Rules, supra note 55, Rule 1.10 comment. Certainly, the Yale TRO Project is portrayed as a single entity, rather than as individual attorneys and students acting independently. The Rules also regard "mutual access to confidential information concerning . . . clients" as indicative of firm status. The Yale TRO Project has found such access necessary to facilitate training and to provide ongoing guidance and support to participants. 
To avoid difficult representation decisions, we strongly recommend that a TRO project build a screening process into its referral system. ${ }^{70}$ Volunteers at the local shelter and Legal Assistance personnel who screen calls from potential clients of the Yale TRO Project are sensitive to clients' needs and may direct abused women to services, such as counseling, which they may prefer to legal advice. Thus, when a project participant meets with a client after screening, there must be a presumption to represent that person.

\section{Confidentiality}

As the client's advocate, the student owes her the same duty of confidentiality as does an attorney. ${ }^{71}$ Confidentiality cannot be overemphasized in a student-run project, where the temptation to share details with students outside the project always exists. Confidentiality is crucial to establishing and maintaining the client's trust in the legal process and to encouraging full communication with the attorney. ${ }^{72}$ Under the Rules, the attorney has a duty to protect not only "matters communicated in confidence by the client but also . . . all information relating to the representation, whatever its source."73 The student should zealously guard the client's right to confidentiality regarding all aspects of her case.

A particularly difficult problem arises if the client reveals that she is or intends to be involved in criminal activity. For example, when filling out a financial affidavit needed to secure a waiver of court filing fees, the client may admit to welfare fraud, or may refuse to reveal all her sources of income. In other cases, the client may threaten the life of the batterer. Whatever the circumstances, an attorney may never disclose a client's past criminal activity. A client's disclosure of ongoing or intended criminal conduct presents a different problem. An attorney must consider carefully whether the client's conduct falls within the permissive disclosure exceptions to an attorney's overarching obligation to maintain client confidentiality ${ }^{74}$ Whether disclosure is allowed depends on the nature of the client's action, and whether the jurisdiction follows the Code or the Rules.

70. The absence of a screening system would greatly increase the potential burden on participating attorneys who use their own insurance to indemnify against potential malpractice actions for refusing to represent certain clients. This potential liability could dissuade interested attorneys from participating. In addition, the absence of a screening process would increase the administrative burdens on students. See supra note 7.

71. MODEL Rules, supra note 55, Rule 5.3 comment (non-lawyer assistants).

72. See MOdel CODE, supra note 54, EC 4-1; see also MODEL Rules, supra note 55, Rule 1.6(a) \& comment.

73. Model Rules, supra note 55, Rule 1.6 comment. The Code and Rules permit disclosure only of intended criminal conduct. See infra text accompanying notes 74-77.

74. We do not discuss the attorney-client privilege, which is distinct from a lawyer's ethical obligation to maintain a client's confidences. See MODEl CoDE, supra note 54, EG 4-4. 
In the case of on-going criminal activity such as welfare fraud, the Code and Rules differ. Under the Code, an attorney may reveal the "intention of his client to commit a crime and the information necessary to prevent the crime." ${ }^{375}$ Thus, absent other law or a court order to the contrary, ${ }^{76}$ disclosure is permitted but not required. The Rules, however, permit disclosure only when the client threatens murder or bodily harm to another; under the Rules, therefore, an attorney could not disclose a client's ongoing welfare fraud.7

Although an attorney is not required to reveal ongoing criminal activity under the Code and is prohibited from doing so under the Rules, an attorney is barred from participating in that criminal activity by knowingly making false statements to the court. ${ }^{78}$ If a client admits to committing welfare fraud, an attorney should explain to the client that the attorney must refuse to use the false information to obtain a fee waiver. If the client insists on making a false statement, the attorney should withdraw from the case. ${ }^{79}$ If an attorney decides to withdraw, the decision should be explained to the client first; the prospect of delay in receiving a TRO may prompt honesty. If attempts to dissuade the client fail, the attorney should withdraw, but she must not do so in a manner likely to prejudice the rights of the client. The attorney must also allow time for the client to obtain other counsel. ${ }^{80}$

When the client threatens to kill her abuser, both the Code and Rules permit, but do not require, disclosure. ${ }^{81}$ The Rules allow disclosure if an

75. Id. DR 4-101(C)(3) (footnotes omitted).

76. Id. DR 4-101(C)(2).

77. The Rules provides that "[a] lawyer may reveal such information to the extent the lawyer reasonably believes necessary . . . to prevent the client from committing a criminal act that the lawyer believes is likely to result in imminent death or substantial bodily harm." MODEL RuLEs, supra note 55, Rule 1.6(b)(1).

78. Id. Rule 3.3(a)(1). Model Code, supra note 54, DR 7-102(A)(5)-(6).

79. Withdrawal in this situation is clearly permitted under the Rules: An attorney may terminate a representation if "a client persists on a course of action involving the lawyer's services that the lawyer reasonably believes is criminal or fraudulent." Withdrawal is required if the lawyer's services will materially further a course of criminal or fraudulent conduct. MoDEl. RuLes, supra note 55, Rule 1.16 (b)(1); see also id. Rule 1.6 comment (entitled withdrawal). Likewise the Code permits an attorney to withdraw if the client "[p]ersonally seeks to pursue an illegal course of conduct." MODEL. CoDE, supra note 54, DR $2-110(\mathrm{C})(1)(\mathrm{b})$, or "[i]nsists that that lawyer pursue a course of conduct that is illegal or that is prohibited under the Disciplinary Code." Id. DR-110(C)(i)(c). Withdrawal is also permitted under this Disciplinary Rule if the client insists on presenting a claim that is neither warranted under current law, nor supported by a good faith argument for extension or modification. Id. DR 2-110(C)(1)(a). The Code makes withdrawal mandatory in some cases. For example, an attorney must withdraw when her continued employment will result in a violation of another Disciplinary Rule. Id. DR 2-110(B)(2). The Code also requires the attorney to terminate representation if the client brings an action to harass or malign another party, where the attorney's physical or mental condition renders it "unreasonably difficult" for the lawyer to continue the employment, or if the client discharges her. Id. DR 2-110(B). The Rules contain substantially the same guidelines for mandatory termination. See MOdel RulEs, supra note 55, Rule 1.16(a).

80. MODEL CODE, supra note 54, DR 2-110(A)(2).

81. MOdEl CODE, supra note 54, DR 4-101(C)(3); MOdel Rules, supra note 55, Rule 1.6 
attorney reasonably believes that the threat is not an off-hand remark expressing anger, but rather a genuine threat indicating an intention to commit a crime "likely to result in imminent death or substantial bodily harm."82 Even if the client's murderous intent were clear and the attorney made no disclosure, she probably would not be held liable for a breach of her professional responsibility. ${ }^{\mathbf{8 3}}$

It is unlikely that an attorney will be faced with a situation fitting the stringent criteria for disclosure under the Rules. The Yale TRO Project has not had a client who threatened to murder her abuser; indeed, it seems more likely that the women who commit these acts feel so alienated by ordinary legal channels that they do not apply for restraining orders. Nonetheless, should the situation arise, the attorney obviously should counsel the client against any violent actions and take all steps possible to defuse these emotions. Yale TRO Project participants would refer such clients to New Haven Legal Assistance or the local shelter, which maintain lists of counselors competent to help battered women. The attorney might also pursue more powerful sanctions against the abuser such as arrest and criminal prosecution. ${ }^{84}$ Most important, the client should be placed in a shelter or other safe living arrangement where she would be protected from further violent provocation. An attorney truly uncomforta-

(b)(1).

82. MODel Rules, supra note 55, Rule 1.6(b)(1). In Connecticut, however, disclosure is mandatory where the attorney reasonably believes it necessary to prevent the client from committing a criminal act that the lawyer believes is likely to result in imminent death or substantial bodily harm. Conn. Rules of Professional Conduct Rule 1.6(b), reprinted in Conn. Rules of Ct. 522 (West 1986).

83. Hawkins v. King County, 24 Wash. App. 338, 343-45, 602 P.2d 361, 365-66 (1979) (not liable where ethical code does not require disclosure, victim might have foreseen risk, and attorney not directly told of intent to do harm). But see Tarasoff v. Regents of the Univ. of Cal., 17 Cal. 3d 425, 431, 551 P.2d 334, 340, 131 Cal. Rptr. 14, 20 (1976) (in bank) (therapist had duty to warn where he reasonably determined patient posed serious risk to another). The Hawkins court refused to impose a duty on an attorney to warn third parties of possible injury or criminal intent by a client when the parties knew that the client might be dangerous. 24 Wash. App. at 345, 602 P.2d at 365. It distinguished Tarasoff, which imposed liability on a psychiatrist, on three grounds: (1) the potential victims were aware of Hawkins's dangerous nature, (2) Hawkins had not directly informed his attorney of his violent intentions, and (3) the attorney had not been told that his client intended to assault anyone, but only that the client was mentally ill and likely to be dangerous to others. Id. at 344-46, 602 P.2d at 365-66. It has been proposed that attorneys should be subject to civil liability where "it appears beyond a reasonable doubt that the client has formed a firm intention to inflict serious personal injuries of [sic] an unknowing, readily identifiable third party; and . . . the benefit of disclosure outweighs the policies underlying confidentiality." Sands, The Attorney's Affirmative Duty To Warn Foreseeable Victims of a Client's Intended Violent Assault, 21 TORT \& INS. L.J. 355, 373 (1986) (footnote omitted). Even if such liability were imposed, it is unlikely that an attorney would be held liable for violent actions of a battered client, because certainly the batterer would be aware of his victim's anger toward him. It would also be difficult to overcome the burden of showing that the client's intentions were firm and apparent beyond a reasonable doubt.

84. Criminal action against the batterer may be appropriate in many cases, not only where the client has threatened retaliation. But cf. MODEL CoDE, supra note 54, DR 7-105(A) ("A lawyer shall not present, participate in presenting, or threaten to present criminal changes solely to obtain an advantage in a civil matter."). 
ble assisting a client who threatens to harm her abuser may also withdraw from the case. ${ }^{85}$ Ultimately, no broad guidelines for disclosure are feasible: The decision whether to disclose a client's intent to injure can only be made within the context of a specific case. The student and attorney should be aware, however, that numerous steps should be taken before preventive disclosure of intended harmful conduct. In all situations, there must be the strongest presumption in favor of preserving client confidences. ${ }^{88}$ Disclosure should only be made under the very strict exceptions countenanced by the Code and Rules as adopted by the relevant jurisdiction. ${ }^{87}$

\section{Duties Toward the Tribunal}

Under the attorney's supervision, the student represents the client in open court. The student seeks to advocate the client's aims as zealously as the Code and Rules permit. ${ }^{88}$ Since in an ex parte proceeding the opposing side will not be present, the Rules place a burden on advocates to inform the court of "all material facts known to the lawyer which will enable the tribunal to make an informed decision, whether or not the facts are adverse." court that the client has not been physically abused, but rather subjected to psychological battering, or that the battering incident occurred several weeks before the client's application. In short, students must understand that, in an ex parte proceeding, a legal representative owes a duty of candor to the court, as well as a duty of zealous advocacy to the client.

At show-cause hearings, even when the opposing party is unrepre-

85. See supra notes $79-80$ and accompanying text.

86. See MOdel Code, supra note 54, DR 4-101(B); ModeI Rules, supra note 55, Rule 1.6 \& comment.

87. See G. HAZARD, supra note 63, at 42 ("Disciplinary Rules . . make preservation of a client's secrets a value preferred over everything except interdicting crimes of violence").

88. Model Code, supra note 54, Canon 7. The Rules phrases the attorney's duty as one of "reasonable diligence and promptness." MODEL RuLes, supra note 55, Rule 1.1, 1.3.

89. MODEL Rules, supra note 55, Rule 3.3(d). The attorney's obligation to inform the tribunal fully of all material facts takes on increased importance when it is understood that an ex parte order may deprive an alleged abuser of his home. In New Haven, judges are sometimes reluctant to grant the victim possession of a jointly owned or leased residence for fear that the abuser will have no alternative place to stay. Connecticut law provides that, after a hearing for which the alleged abuser must receive notice, the court may provide relief that can include enjoining the abuser from entering the dwelling of the victim. ConN. Gen. STAT. § 46b-15(b)(3) (1985). In addition, where "an applicant [victim] alleges an immediate and present physical danger to the applicant, the court may issue an ex parte order granting such relief as it deems appropriate." Id. § 46b-15(b). The Yale TRO Project has generally argued that the victim should receive possession of the home, especially where the victim is caring for children. See supra notes 26-29 and accompanying test. For an analysis of the procedural due process implications of ex parte proceedings in battering cases, see Taub, Ex Parte Proceedings in Domestic Violence Situations: Alternative Frameworks for Constitutional Scrutiny, 9 HoFSTRA L. Rev. 95 (1980) (recognizing property and liberty interests of alleged abusers in ex parte proceedings, but arguing that ex parte orders meet constitutional standards). 
sented, the attorney has a different duty. Because such hearings are adversarial, neither the Code nor the Rules require the advocate to present mitigating facts, so long as the opposing party has had adequate notice and prefers either to waive his appearance or to appear without counsel. In this situation, the student's only obligation is to make clear her position as advocate for the client, but she may recommend to the unrepresented party that he obtain counsel. ${ }^{90}$

\section{Negotiating a Settlement}

Instead of proceeding with the adversarial hearing in which the client seeks an extension of the temporary protection order, it is often more advantageous to negotiate a settlement. ${ }^{91}$ Negotiations often make progress because batterers will agree to an extension of the protection order provided they retain the right to deny the allegations of abuse. The student and the attorney must take special care in negotiating settlements and presenting the terms to their client because what may seem inconsequential to them may be vital to the victim. For example, the client may give great symbolic importance to the stipulation that the abuser not be allowed to enter the house to gather his belongings; she might prefer to package them and leave them outside the door for him to pick up. The student should make every reasonable effort to accommodate the client's wishes so that the settlement agreement will be as empowering as the temporary order. $^{.2}$

\section{G. Extra-Legal Considerations}

In addition to the organizational and ethical issues involved in sustaining a successful project, a student-run TRO project will encounter significant extra-legal problems, some of which inhere in the project itself. This section explores important extra-legal concerns that the Yale TRO Project has found compelling and suggests responses to these challenges. While this section cannot be exhaustive, it should assist readers in understanding some of the most complex dimensions of such an undertaking.

90. See MODEL Rules, supra note 55 , Rule $4.3 \&$ comment.

91. Settlement negotiations are generally easier when the abuser is represented by counsel. By settling, the abused client can often obtain favorable terms, and the abuser can avoid the res judicata effect of an adversary hearing. Otherwise, findings at the hearing can affect a pending divorce action. Settlement may also be advantageous where the client has a weaker case for extended protection. For example, judges are sometimes reluctant to issue permanent orders if the victim has allowed the batterer back in the home during the pendency of the temporary order. Negotiating a settlement would avoid the chance that the abuser could raise this potentially damaging fact.

92. Cf. MODEL RuLES, supra note 55, Rule 1.4 \& comment (" $[\mathrm{t}]$ he client should have sufficient information to participate intelligently in decisions concerning the objectives of the representation and the means to which they are pursued, to the extent the client is willing and able to do so"). 
The discussion examines, first, "fundamental assumptions" issues, and second, "sensitivity" issues.

\section{1. "Fundamental Assumptions" Issues}

\section{a. Serving Non-Traditional Clients}

An important initial concern is whether to assist non-traditional clients who qualify for TROs under the applicable statutes. Although battering is overwhelmingly a phenomenon of male-female dating and marital relationships, it can also occur in gay and lesbian relationships, ${ }^{93}$ between a paid caregiver and an elderly patient, ${ }^{94}$ between a child and a parent, ${ }^{95}$ between roommates, or in any other domestic relationship. ${ }^{96}$ Although the Yale TRO Project was begun specifically for women battered by men, calls from non-traditional clients soon led us to reevaluate our purposes. We thought that it would be both unethical and unjust to turn away anyone in need of a protection order, regardless of the nature of the battering situation, so long as the client was covered by the applicable statutes. Accordingly, our training now alerts students that they may be serving clients in many different kinds of battering relationships, and that they have both legal and ethical obligations to assist non-traditional clients as ably as they do traditional ones.

We have also learned that simply deciding to assist non-traditional clients may be inadequate. A project's response to the problems of a nontraditional community must be tailored to the needs of that group. TRO directors in communities with large discrete populations (the elderly or non-English speakers, for instance) should make every effort to understand the scope of the problem within the specific community, the adequacy of existing resources, the special needs of the group, and whether and how the project could best respond to those needs. This year, for example, the Yale TRO Project has begun to explore with local community leaders whether and how we might provide additional assistance to battering victims within New Haven's sizeable lesbian and gay community, and how we can ensure that all who need our services are not hesitant to seek them.

93. See, e.g., National Coalition Against Domestic Violence, Naming the Violence: Speaking OUT About Lesbian BatTering (K. Lobel ed. 1986). The National Coalition Against Domestic Violence, based in Washington, D.C., maintains a task force on lesbian and gay domestic battering issues.

94. See generally Elder Abuse: The Facts, Response, Fall 1984, at 19 (survey of recent major studies on abuse of the elderly).

95. See, e.g., id. (elderly often abused by their children).

96. See, e.g., Bursten, Isolated Violence to the Loved One, 9 Bull. Am. Acad. Psych. \& L. 116 (1981). 


\section{b. "Ideological Evolution"}

Another challenge, one that we have touched on throughout, concerns what we call a TRO project's "ideological evolution." As a project grows and gains new members, its original goals and orientation will change. For instance, the current Directors of the Yale TRO Project differ about how strongly to pursue the Project's original feminist goals. Several would like to see more consideration given to feminist theory and procedures, while others wish to see the Project expand as it will, and are most concerned with becoming more efficient. The issue is of more than theoretical importance, as it goes to the heart of how training, recruitment, and even community outreach should be conducted. ${ }^{97}$ We believe that these differences of opinion are inevitable by-products of growth and success, and that they are healthy so long as they do not hamper our ability to provide legal services to our clients. We understand the importance of open communication and full consideration of matters at hand during Directors' meetings. We have found that flexibility and willingness to put project needs above Directors' own interests is essential to sustaining the Project.

\section{2. "Sensitivity" Issues}

In many ways, the most basic and complex problems facing any TRO project are those we call "sensitivity" issues-issues related to good communication between the client and the student intern. For the most part, students and clients engage in a mutually satisfying relationship. In our experience, clients do not have fundamental psychological problems; ${ }^{98}$ students need no highly specialized interviewing skills to communicate with their clients. However, student interns and clients alike approach the TRO process with many biases and prejudices, often unspoken, that can be harmful to effective representation of the battered woman. While educating the clients about their prejudices is rarely, if ever, appropriate, educating students about theirs certainly is. Only when the client genuinely trusts the student intern and believes that the student is sympathetic and not judgmental can the client feel free to provide the often embarrassing details needed to prepare a solid case for the court. Equally important,

97. For instance, one Director of the Yale TRO Project met considerable resistance from a past Director when attempting to interest various newspaper and radio reporters in covering a reception given in honor of the Project's volunteer attorneys. The former Director believed that the publicity was likely to turn the affair into a "media event" and thereby distort the public's view of the Project and its feminist aims. Current Directors have decided that media coverage is important.

98. See Fleming, supra note 3, at 76-79 (summarizing studies criticizing those mental health professionals who assume battering is caused by victims' masochism or other psychological problems); id. at 79-80 (victims' psychological problems are result of battering, not cause); see also Walter, supra note 3, at 20-21 (author, a clinical psychologist, examined allegedly psychotic battered women and found "insufficient evidence" of disorders). 
only when the student learns to control or relinquish her own preconceptions about domestic violence can she effectively listen to and help the client.

The list of sensitivity issues is probably endless. Four that have been most pronounced in the Yale TRO Project are: the general frustrations of dealing with victims of battering, cultural and class differences, racism, and sexism. We examine each in turn.

\section{a. Frustration}

Throughout the Project's history, student enthusiasm has run high. Students respond positively to the opportunity to help battered women. However, a vexing issue for the Yale TRO Project is how to maintain student motivation as participants confront the many frustrations of dealing with victims of battering. In the experience of the Yale TRO Project, most women who make initial TRO appointments cancel, never show up, or decide during the interview-for reasons that may seem irrational to the law student-not to go through with the process. Many who obtain TROs nevertheless allow the batterer back into the house or otherwise maintain physical contact during the effective dates of the order, even at risk to their own or their children's safety. And many who obtain TROs choose not to seek permanent orders, although it would seem clearly in their best interest to do so. Many of our clients are also repeat clients: some keep attempting to obtain a TRO but never complete the process, while others have received repeated protection orders, often against the same batterer, yet return to their abusive domestic arrangements. ${ }^{99}$

Students can easily become hurt, frustrated, or angry at their clients for not following through with the TRO process. Students may believe that the client's withdrawal from the case implies that the student has failed in some way or that the work done up to that point was futile. Indeed, some students have left the Project in frustration for these reasons. Others have provoked hostile comments from clients-or, equally troubling, reticence. Once students learn to identify and anticipate their own negative reactions, however, they can overcome a tremendous barrier not only to their effectiveness as legal advocates but also to their own human understanding.

Students should be assisted in surmounting these frustrations by careful training. First, they must be educated about the "syndrome" of bat-

99. Because the Yale TRO Project does not keep records, accurate statistics are impossible to determine. Workers at New Haven's Project for Battered Women, however, estimate that only one in ten women who inquire about obtaining protection orders, and who may benefit from such orders, actually completes the process. Our estimate is that as many as $70 \%$ of the women referred to the Yale TRO Project do not complete the initial ex parte process. 
tering. ${ }^{100}$ When students understand that there are many reasons-financial, societal, and emotional-that lead a victim of battering to choose to return to the batterer, they may be better able to accept a client's choice without anger or frustration. ${ }^{101}$ Students also need to anticipate, recognize, and respond to their clients' feelings of helplessness and powerlessness. Training in this area should be as active and interactive as possible. One extremely helpful exercise is to have students recall times in their own lives when they felt particularly powerless to change a troublesome situation. ${ }^{102}$ Above all, it is important that through training students learn to respect their clients' choices and come to understand that "this case is not about you." 103

Learning about battered women's syndrome is not enough. It is equally important that students learn more about themselves. Many students approach the Project over-optimistically, and somewhat egotistically. They see themselves as "saving" their clients from a terrible fate. ${ }^{104}$ In fact many students, in an effort to be maximally useful, will do more than is required-and more than is helpful-for their clients. Such unnecessary tasks include phoning the client daily when she does not request this, giving the client the student's home phone number, ${ }^{105}$ babysitting, or in general becoming highly emotionally involved in the case. Students may convince themselves that they are doing these things in the client's best interest, when in fact they may be exerting unwelcome pressure on the client or being unnecessarily intrusive. To be sure, clients themselves may encourage these responses. ${ }^{108}$ Once a client knows that a student is on her side, for instance, she may welcome the rare chance to pour out her grievances, or expect the student to perform inappropriate or impossible tasks. When clients halt the TRO process at any time prior to obtaining a per-

100. See supra note 3 .

101. See generally R. Dobash \& R. Dobash, supra note 2, at 75-90; R. LANGLEy \& R. Levy, Wife Beating: The Silent Crisis 111-25 (1977); Prescott \& Letko, Battered Women: A Social Psychological Perspective, in BATIEREd WOMEn: A Psychosocjolorical Study of Domfstic VIOLENCE, supra note 2, at 72 .

102. Another helpful exercise is to have students assume various roles in mock interviews and mock court sessions. Discussions with women who have been in battering relationships is also extremely helpful. Battered women's shelters may be able to provide a list of willing discussants. Occasionally, the Project has distributed hypothetical case studies that raise ethical dilemmas that the Project examines as a group. The list of possible sensitivity exercises is limited only by the imaginations of Project participants.

103. Interview with Mary McCarthy, Faculty Advisor, Yale TRO Project, in New Haven (Nov. 11, 1986).

104. See J. Fleming, supra note 3, 136-39, 147-49 (1979) (rescue fantasies are quite common among both battered women and legal and support personnel with whom they come into contact).

105. One of the authors did this only to discover that her phone number fell into the hands of the angry batterer-husband. For a while the student received many "hang-up" phone calls that she suspected might have come from the husband, but fortunately nothing else happened.

106. J. Fleming, supra note 3, at 136-37. 
manent order, as most of them do, the overinvolved student can feel overwhelmed by negative reactions.

Proper training can help teach appropriate professional distancing. Before they enter an attorney's office, students must be alerted that their own "savior syndrome," although understandable, is ultimately disrespectful and unhelpful to the client; it may perpetuate her feelings of being passive and controlled, or quite unfairly add to a sense of futility and hopelessness. ${ }^{10 z}$ Training also should inform students that, sadly, a TRO project itself is only a band-aid solution to the profoundly complex dilemma of domestic violence in our society, and that they should not expect more of themselves, their clients, or the TRO process than is reasonable. ${ }^{108}$ Role-playing sessions in which students are asked to deal with indecisive, defensive, or ambivalent responses from clients are especially instructive in helping students adjust their expectations, particularly if the role plays allow ample time for analysis and discussion after each scenario. ${ }^{108}$ Frequent meetings in which participants, either in small or large groups, discuss their feelings and impressions of the TRO process are also useful. Getting feedback from attorneys and clients should be encouraged whenever possible.

\section{b. Cultural and Class Differences}

In all likelihood, the client will be of a different cultural, economic, and/or educational background than the student. ${ }^{110}$ These disparities may create difficulties in communication that make rendering the most effective assistance difficult. ${ }^{111}$ Many minority women at New Haven's battered women's shelter report feeling intimidated at the thought of being assisted by Yale law students, to whom they feel they will not be able to express

107. Id.

108. See Wesley, Breaking the Vicious Circle: The Lawyer's Role, 6 Vr. L. REv. 363, 372 (1981).

109. A typical role play might involve a mock interview session in which the student assumes the role of a client who comes to the office with small children, who is uncertain about obtaining a TRO, and who must retain possession of her apartment during the TRO time period. Discussion should focus on whether the student assuming the role of student interviewer obtained enough specific information from the interview to write a convincing affidavit, interacted well with the client, handled ethical issues properly, etc. Following the discussion, the role play could resume as a mock courtroom session.

Role plays can be preassigned and rehearsed by students who may or may not be involved in the Project (ex-actor law students are especially convincing in these situations), or roles and situations may be assigned at random during training sessions. Trainers shold be careful to emphasize that most TRO cases do not present major problems and in fact are both rewarding and straightforward.

110. Studies suggest that middle- and upper-class victims of domestic violence may be far less likely to seek help than poorer women. See J. Fleming, supra note 3, at 134.

111. Id. at 130-36; cf. Gil, The Social Context of Domestic Violence: Implications for Prevention, 6 VT. L. REv. 339 (1981) (system of "structural violence," including class differences, contributes to incidence of domestic violence). 
themselves adequately. Clients may also be embarrassed to report important details of their domestic situations to students whom they think will, for cultural or class reasons, disapprove. Students themselves might be afraid to ask certain questions, or may not know how to ask questions without sounding overly intrusive or demeaning. Although this last problem is probably endemic to the TRO interview process, it may also be a function of class and cultural disparities between student and client.

Because such barriers may impede effective assistance, it is imperative that training sessions make students sensitive to such "difference" issues. Through mock interviews, role plays with community leaders, and largeand small-group sessions, students must become aware that the many verbal and nonverbal signals they send can reinforce a client's sense of helplessness and her reluctance to seek assistance. These signals can be unconscious, such as when a student positions herself across a desk from a client rather than sitting alongside her. Gestures or symbols of authority and distance, in the TRO context, can be especially inhibiting to clients. The signals may be subtle, such as the student's coming to the interview or court appointment laden with jewelry or wearing a very expensive suit, or the student's addressing a client by her first or last name without having asked the client's preference. Other signals are more blatant, such as inattention, correcting the client's English, or being rude to or impatient with any children the client brings along. In addition, since the client interview process may represent the first opportunity student interns have had to be placed in the role of a legal "authority," they, quite understandably, might be tempted to play the role to the hilt. Students may have been told in clinicals and elsewhere to be business-like and formal, and may not realize that in the TRO context this stance may be inappropriately chilling. Only the most careful attention to the manifold variations of these unbeneficial attitudes and assumptions will enable the student to best serve the client. It is important to elicit ongoing feedback from clients, shelter workers, and attorneys, as well as from the students themselves, on their feelings about and reactions to the interview process. One way of canvassing reactions is to give each participant a self-addressed, stamped envelope and a questionnaire that she can fill out at her leisure after the TRO interview. Another is to invite battered women who have used Project services in the past to participate in training sessions. ${ }^{112}$

112. The Yale TRO Project has also benefited greatly from training sessions with the Director of the New Haven Project for Battered Women, who has many years' experience providing support services to battered women in the New Haven area. At the beginning of every semester, the Director not only discusses the problem of battering with Project participants but also provides an overview of how the Project is perceived by clients and potential clients. 


\section{c. Racism}

A related "difference" issue is racism. ${ }^{113}$ Students may come to an interview with preconceptions about those of a different race that hamper their ability to speak to the client as an equal. The client, in turn, may have her own special way of relating to persons of a different race. Often the racism is subtle, expressing itself in tones of voice or facial expressions. It may also present itself in assumptions about the client's lifestyle, economic level, employment, or housing situation. Many of the training techniques discussed above are useful in alerting students to the presence and effects of racism. The pervasiveness of racism in our society, and its sheer tenacity in many of our institutions, including law schools, suggest that the issue of racism may need to be constantly addressed. Otherwise, a project that is intended to help others may actually help to reinforce outmoded and distasteful stereotypes.

\section{d. Sexism}

Most batterers are men; most victims, women. These battered women may invest men in general, and particularly men in visible positions of authority, with enormous power over them; they may fear and be extremely deferential to men. ${ }^{114}$ Moreover, male students, albeit unintentionally, may respond to female clients in particularly patronizing ways, such as calling a client "dear," or refusing out of a misplaced sense of "chivalry" to ask a client important details about a battering incident. These responses often compound a battered woman's sense of powerlessness and inequality, ${ }^{116}$ and are especially damaging in an interview in which a woman must detail instances of male violence. ${ }^{116}$

Given these factors, the participation of male students (and attorneys) in a TRO Project becomes problematic. Nevertheless, excluding men from a Project altogether is also troubling. Federal ${ }^{117}$ and state ${ }^{118}$ laws, as well

113. See J. Fleming, supra note 3 , at 130-33.

114. Id. at 81-82; of. Stallone, supra note 14, at 495-97 (critique of theories that focus on victims' "inadequacies").

115. See generally L. WALKER, supra note 3, at 148.

116. Some clients may prefer to talk only to women, or only to men. However, the Yale TRO Project has never encountered clients expressing either preference. The exigencies of the scheduling process and the random nature of client-student-attorney assignments would make it difficult to accommodate such requests.

117. Education Amendments of 1972, Title IX, 20 U.S.C. $\$ 168$ (a) (1982) (prohibiting discrimination based on sex in educational programs or activities receiving federal funds).

118. See, e.g., Fla. Ed. Equity Act, FlA. STAT. § 228.2001 (1982) (prohibits sex discrimination in any educational program or activity conducted by a public educational institution receiving state or federal financial assistance); MAss. GEN. LAws ch. 151C, \& 2(d) (1972) (prohibiting sex discrimination by public educational institutions in admission or admission to programs); OR. REV. STAT. § 659.150, as amended through 1985 (prohibiting sex discrimination in educational programs, services, schools, or activities funded wholly or in part by the state legislature). 
as many university regulations, ${ }^{118}$ prohibit sex discrimination in educational programs. Whether or not TRO project participants receive credit from their law school, a TRO project such as the one described in this Comment remains an educational program. However, even if it were not illegal, excluding men from a project might have serious consequences. Such selectivity limits the amount of help available to victims of battering, ${ }^{120}$ perpetuates sexist stereotypes, and contributes to the ghettoization within the legal community of battering as a "woman's" (i.e., unimportant) issue. A far more sensible solution to the difficulty of integrating men into a TRO project is to provide careful training.

The same interactive training techniques that are helpful in dealing with issues of frustration, cultural and class differences, and racism, are also useful in combatting sexism. As in all training involving sensitivity issues, TRO training should not make students feel that they are being personally or generically attacked. Rather, it should convey that by acknowledging ingrained biases, students improve their effectiveness as dedicated advocates and also improve the project's ability to deliver a community service.

\section{Conclusion}

In a vast majority of the cases in which a client desired a protection order ${ }^{121}$ the Yale TRO Project successfully obtained the requested relief. Despite the Project's high success rate, protection orders have their limitations. A TRO cannot physically shield the victim from violence: The burden is on her to call the police when the abuser threatens, and then the police must adequately enforce the order. ${ }^{122}$ A protection order will not

119. See, e.g., Yale LAw SCHOOL BulletiN, supra note 6, back cover page:

The University is committed to basing judgments concerning the admission, education, and employment of individuals upon their qualifications and abilities and affirmatively seeks to attract to its faculty, staff, and student body qualified persons of diverse backgrounds. In accordance with this policy and as delineated by federal and Connecticut law, Yale does not discriminate in admissions, educational programs, or employment against any individual on account of that individual's sex....

120. Currently, $40 \%$ of the Yale TRO Project's participants are male.

121. In some cases, the client determines that a TRO would not be appropriate. For example, she may decide that counseling will better achieve her aims of eventual reunion with the abuser and treatment of his underlying problems. Commentators have not unanimously endorsed protective orders as a solution to battering. See, e.g., Bethel \& Singer, Mediation: A New Remedy for Cases of Domestic Violence, 7 VT. L. REv. 15 (1982) (urging mediation in certain battering cases). Resort to non-legal methods of preventing domestic violence has been criticized as a failure to understand the seriousness of a violent situation and for placing the blame and responsibility on the victim. See Lerman, Mediation of Wife Abuse Cases: The Adverse Impact of Informal Dispute Resolution on Women, $7 \mathrm{HARV}$. WOMEN's L.J. 57, 71-97 (1984); see also supra text accompanying notes 57-70 (criticizing decision to decline representation).

122. The police's failure to cooperate continues to be a pressing problem for battered women. Indications of such failure include responding slowly to domestic violence complaints, blaming the victim for her plight, and refusing to arrest the batterer. See, e.g., Bowker, Police Services to Battered 
provide a forty year old housewife with job skills, nor can it find child care for her three children. ${ }^{123}$ It will not ease the guilt a woman may feel about breaking up her marriage. ${ }^{124}$ Nor will it abate the victim's anger, frustration, or even love for her abuser. Indeed, many clients of the Yale TRO Project eventually return to their abusers after receiving a protection order. ${ }^{125}$

Yet the importance of the TRO process as an empowering experience cannot be overestimated. For many abused women, a TRO can be an important first step toward breaking out of a battering relationship. The client may, for example, use a restraining order to protect herself against an abusive spouse until a divorce can be obtained. ${ }^{128}$ Or, a client may seek

Women: Bad or Not So Bad?, 9 CRIM. JUST. \& BeHAv. 476, 485-86, 490 (1982). In a study of 146 battered women in Wisconsin, Bowker found that although women requested arrests in $82 \%$ of incidents, police actually made arrests in only $14 \%$ of the incidents. Id. at $485-86$. Another study found that the police denied $61 \%$ of the arrests requested by battered women. Id. at 485-86. A third study found that $70 \%$ of battered women considered the police not to be helpful in ending violence. Roy, $A$ Current Study of 150 Cases, in BatTered Women: A Psychosocial Study of Domestic VioLence 25, 35 (M. Roy ed. 1977); see also, e.g., Note, Battered Women and the Equal Protection Clause: Will the Constitution Help Them When the Police Won't?, 95 YALE L.J. 788 (1986) (arguing that police policy not to arrest batterers denies victims equal protection under Fourteenth Amendment). A number of states have adopted mandatory arrest laws. For example, the relevant Connecticut provision states:

Whenever a peace officer determines upon speedy information that a family violence crime has

been committed within his jurisdiction, he shall arrest the person or persons suspected of its

commission and charge such person or persons with the appropriate crime. The decision to

arrest and charge shall not (1) be dependent on the specific consent of the victim, (2) consider

the relationship of the parties or (3) be based solely on request by the victim.

ConN. Gen. STAT. § 46b-15(2)(a) (1985). While Connecticut has had little experience with mandatory arrest under its new statute, other states have found that such provisions reduce the incidence of domestic violence. A study in Minneapolis found that arresting the batterer produced a lower recidivism rate than ordering the man to leave the residence or mediating the dispute. Pastoor, Police Training \& the Effectiveness of Minnesota "Domestic Abuse" Laws, 2 LAw \& INEQUALITY 557, 595 (1984) (citing L. Sherman \& R. Berk, The Specific Deterrent Effects of Arrest for Domestic Assault (July 25, 1983) (unpublished paper available from The Police Foundation, Washington, D.C.)).

123. Commentators have argued persuasively that many women remain in battering relationships because of economic considerations, such as housing, child care, and financial support, and not because of "masochism, pathology, or acceptance of violence" by women. E.g. R. DOBASH \& R. DOBASH, supra note 2, at 156-60.

124. See supra note 66 .

125. Walker identifies a three stage cycle of violence: (1) the tension-building stage during which minor battering incidents occur and escalate; (2) the acute battering incident, characterized by the uncontrollable discharge of built-up tensions; and (3) the kindness and contrite behavior stage, in which the batterer convinces his victim of his remorse and persuades her to stay in the relationship. $L$. WALKER, supra note 3, at 55-70. Walker suggests that each time a woman goes through this cycle, her self-esteem and ability to see her way out of the relationship are diminished. Id. at 69 . Battering can be seen as an expression of patriarchal domination, and thus difficult to eradicate without a fundamental reordering of women's roles in society. See R. DoBASH \& R. DoBASH, supra note 2, at 1-13. It has been suggested that only radical political reform can eradicate battering. See Gil, supra note 111 (discussing battering as response to socially evolved and maintained class systems and arguing for egalitarian and non-violent social, economic and political institutions to eliminate battering).

126. Connecticut's family violence legislation provides that "[n]o order of the court shall exceed ninety days, except that an order may be extended by the court upon motion of the applicant for such additional time as the court deems necessary." ConN. GEN. STAT. § 46b-15(d) (1986); see also id. § 46b-38 (spousal violence). Connecticut courts have on occasion issued indefinite orders. See, e.g., In re 
a TRO to end an abusive live-in relationship. As longtime victims, many battered women may not have understood that there are legal mechanisms, support groups, and individuals ready to help them. To these women, the availability of legal relief acknowledges that society will not tolerate battering - they are not alone. Assisting a battered woman can be a fulfilling experience indeed, for the law student and attorney alike.

White (Conn. Super. Ct. Oct. 31, 1986) (court order after hearing). 